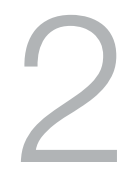

\title{
Ancient magic and religious trends of the rāhui on the atoll of Anaa, Tuamotu
}

\section{Frédéric Torrente}

This paper is based on vernacular material that was obtained from one of the last of the ancient vanaga, masters of pre-Christian lore, Paea-a-Avehe, of Anaa ${ }^{1}$ Island.

\section{Introduction}

Throughout the last century, in the Tuamotuan archipelago, the technical term rāhui has been applied to 'sectors' (secteurs): specified areas where the intensive monoculture of the coconut tree was established, at that time and still today, according to the principle of letting these areas lie fallow between periods of cropping. The religious reasons for this method have been forgotten. The link between Christian conversion and the development of coconut plantations has changed the Tuamotuan atoll's landscape through the introduction

1 Anaa is the Tahitian name of this atoll ('Ana'a). In Tuamotuan language, it should be noted 'Ganaa' or 'Ganaia'. This atoll is situated in western Tuamotu, in the Putahi or Parata linguistic area. 
of new modes of land occupation and resource management. In old Polynesia, the political and the religious were intertwined, as well as man and his symbolic and ritual environment.

Political and social aspects are studied elsewhere in this book. This essay considers the religious and ritual picture of pre-European life on the islands, and shows how religious concepts influenced man in his environment.

The Tuamotuan group of islands represents the greatest concentration of atolls worldwide; they are a unique, two-dimensional universe, close to water level and lacking environmental features, such as high ground, that could provide a place of refuge. This explains the extreme mobility of the vulnerable Tuamotuan societies, and their adaptability to change, be it of human origin or environmental. The Polynesian religion was based on prohibitions organised inside systems. Man was, thus, able to know where he stood according to his rank, in a world that identified sacred things or locations that had to be set apart. Shore asserts that this separation was translated within the opposition tapu/noa, which is undistinguishable from the concept of mana. ${ }^{2}$ This strict opposition, much less porous to outside factors than the one of $A o / P o$ (life and visible world/death and invisible world), is key to understanding how Polynesian societies function. Man was obliged to respect the rules that governed social behaviour, including moral or practical responsibilities and those things or actions that were strictly prohibited. $^{3}$

The functions of these permanent or temporary prohibitions varied according to one's point of view. They allowed one to find his place on the continuum god/humans/ancestors/origin of life, and during religious rites that perpetuated the cosmic order. Such prohibitions protected the god's power (mana), and fed the dread (rikarika) of supernatural sanctions. The same prohibitions reinforced the divine power of a chief's legitimacy, keeper of world order and holder of the group's perennial identity, maintainer of social cohesion.

2 Shore, B., 1989. 'Mana and Tapu: a new synthesis'. In A. Howard \& R. Borofsky (eds), Developments in Polynesian Ethnology. Honolulu: University of Hawai'i Press, pp. 137-74.

3 Bender, A. \& Beller, S., 2003, 'Polynesian tapu in the deontic square. A cognitive concept, its linguistic expression and cultural context'. In R. Alterman \& D. Kirch (eds), Proceedings of the Twenty Fifth Conference of the Cognitive Sciences Society, pp. 131-38. 


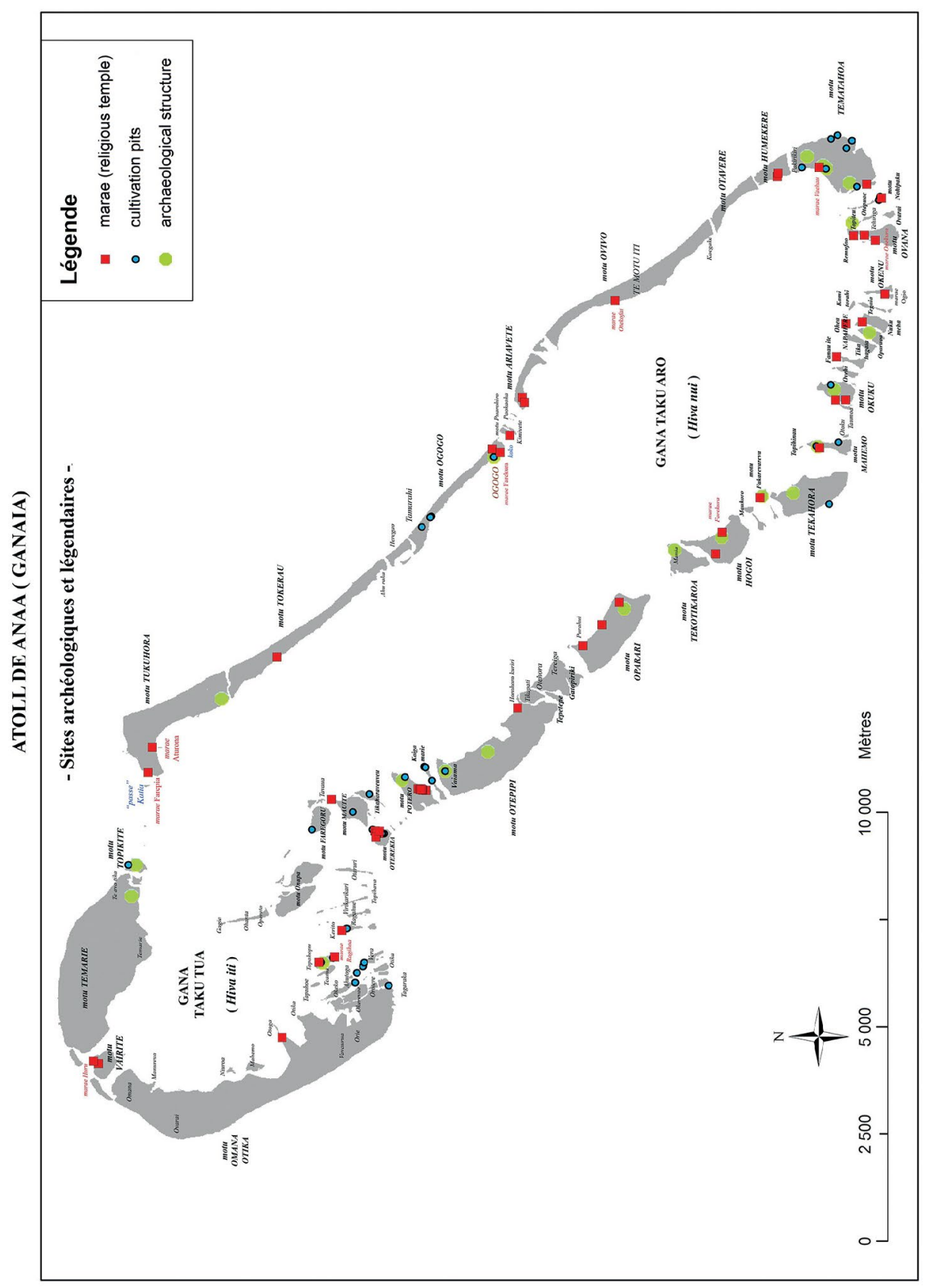

Figure 2: Map showing the locations of marae and archaeological structures on Anaa

Source: Frédéric Torrente 
The word rāhui derives from the Eastern Polynesian root raafui, which means to prohibit (Polynesian Lexicon - Pollex). The Maori give the following definition: 'to protect by a rahui - i.e. by a mark set up to prohibit persons from taking fruit, birds etc., on certain lands, or to prevent them from trespassing on lands made tapu' ${ }^{4}$ On Mangaia: 'raui, sacred, restricted by tapu, a mark of tapu, generally shown by the setting up of a coconut leaf plaited in a particular way'. ${ }^{5}$ Williams notes: 'A mark denoting a sacred spot, as a burial place, a mark to indicate that shellfish, timber, flax or any other commodity in the neighbourhood is to be preserved. Made sacred, preserved' ${ }^{6}$

In the Tuamotu, rāhui means: 'to prohibit, interdict, forbid taking, as the food of certain lands. A prohibition laid on lands or on crops. Closed, forbidden, as a land from which certain foods may not be taken'. ${ }^{7}$ Răhui is, thus, a temporary prohibition, the area of which is indicated by a physical sign, that is established on a food resource and on one's own land. The fear of supernatural sanctions derived from the invisible active power of the rāhui was enough for it to be respected.

\section{To establish a rāhui}

Any man inside greater Polynesia, notwithstanding his rank, could put a rāhui on his own land or on a particular type of resource, ${ }^{8}$ which shows the importance of the rāhui inside the private sphere. This is still well entrenched in Maori culture.

The rāhui could be applied to resources obtained from the land, as well as to marine resources (portions of lagoons, portions of reefs).

In the Tuamotus, the divine chief (ariki) was also the master of rites on his sacred temple called marae ariki. Each descent line (gāti) had a tutelary god who was recognised as belonging to the whole atoll, as being the father of a divine succession that gave birth to a succession

\footnotetext{
4 Williams, H.W., 1852. A Dictionary of the Maori Language, London: D.C.L.

5 Tregear, E., 1891. The Maori-Polynesian Comparative Dictionary. Wellington, New Zealand, p. 385.

6 Williams, 1852.

7 Stimson, J.F. \& Marshall, D.S., 1964. A Dictionary of Some Tuamotuan Dialects of the Polynesian Language. Massachusetts: Peabody Museum of Salem \& The Hague: The Royal Institute of Linguistics and Anthropology, p. 427.

8 Wilson, W., 1799, A Missionary Visit to the Southern Pacific Ocean, Performed in the Years 1796, 1797, 1798, in the Ship Duff, Commanded by Captain James Wilson. London.
} 
of chiefs. ${ }^{9}$ One of the ariki's prerogatives was to place temporary prohibitions linked to the important milestone ceremonies: stages of the chief's life, prestigious visitors, wars and seasonal rituals. When a chief wanted to put a rāhui on a food resource as a preliminary to a feast, he acted through a tahuga (the priest on the marae), who called upon the gods, taking the oath that they would be invited to the feast.

If a person of inferior rank wished to protect his plantations, he would go through a tāura (expert in divination and magic), who buried an object at the base of the tree made mana by the incantation called karakia (in the Tuamotus and among the Maori). A symbol would be put on the tree as a message for potential transgressors. The incantation was to the mauri (life-giving energy) of the tree, for it to become full of fruit and protected through the awakening (faka ara) of the destructive power of the rāhui applied against a potential thief.

Davies claims that in the Society Islands, rahu is the name of the incantation made to apply a prohibition, another sense of the word being 'to engender, to produce, to create, to make appear, to bring to the world, synonymous with arahu, to spring, as seed or young shoot. Rahurahu is an expression of the sacred or of the prohibition, synonymous with tapu, as in the phrase ai rahurahu (to eat prohibited food)'. ${ }^{10}$

\section{The rāhui inside a system}

The rāhui is first of all a physical sign indicating a prohibition. More than a simple sign, however, it is part of a system of association by which a material symbol that can be seen by everyone is a mark of the prohibition on access to an invisible but active world. The rāhui is positive in that it protects the physical elements that are not to be touched, and negative and destructive in its effect on the one who would violate the rāhui.

Among the Maori, carved posts (pou rāhui) indicated that a temporary prohibition was placed (rāhuitia) on natural resources such as land, forests, shores or rivers. A piece of material or another object belonging to the custodian would be attached to the post, which might be a simple stake, as a mark of his invisible power.

9 Caillot, E., 1932, Histoire des Religions de l'Archipel des Tuamotu. Paris: Ernest Leroux.

10 Davies, J., 1851, A Tahitian and English Dictionary with Introductory Remarks on the Polynesian Language and a Short Grammar of the Tahitian Dialect. Tahiti: printed at the London Missionary Society's Press. 
The pou rāhui is inhabited by the active power of the rāhui. The image's threatening aspect underscored the danger of going further. The 'heart' of the rāhui was a hidden stone (whatu, fatu, pofatu) which contained the mauri, hidden so as not to be manipulated by an expert diviner (tāura) enfeebling its mauri. At first, the power entrusted inside the stone had to be woken up, or activated (fakaoho) through a karakia calling upon the vertical continuum between $A o$ and $P o$ and, so to speak, charging this stone with mana and sharpening its teeth. ${ }^{11}$

Near the pou rähui was meant to be the abyss (waro) the entrance to the Po into which the violator would fall. The pou rāhui wore a man's girdle (maro), which was a decoy, the real maro being hidden at some distance. The functional physical whole of the hidden maro and whatu was called the kapu of the pou rāhui. Eventually there was attached on the pou rāhui only a piece of the chief's clothes or a piece of material.

The planting of pou rāhui was linked to the ownership of the land:

These posts were erected as indicating a taking possession of the land - a tìtiri, or erecting the sacred mark of the rāhui. ${ }^{12}$

Titi o kura, the setting up of the kura, that is painting the post supporting a house with red ochre, as tapu indicating the sacredness of the building. ${ }^{13}$

In the Society Islands, when there was a significant rāhui put on by the chiefs, one of the ways to ritually reactivate the existence of the cosmos and to reiterate their divine origin and their prestige was to establish on the temple a ti'i potua ra'au (carved posts) ${ }^{14}$ or potua aru ('a tree trunk carved on its whole length with $t i^{\prime} i$ images, planted as a guardian of a rahui or a prohibition', ${ }^{15}$ see Figure 3). When the chiefs had decided on a rāhui, these ti'i potua ra'au images, carved back to back, were stood on the meeting places, their bases surrounded by stones, which are reminiscent of the whatu. When the prohibition was lifted, the carved posts were taken out, their mauri having gone. There was another kind of $t i^{\prime} i$ pu răhui, inside the private sphere, for provisional prohibitions

11 Best, E., 1904. 'Notes on the custom of Rahui, its application and manipulation, as also its supposed powers, its rites, invocations and superstitions'. Journal of the Polynesian Society, 13(2): 83-88.

12 White, T., 1892, “The Rahui". Notes \& Queries'. Journal of the Polynesian Society 1(4): 275-76.

13 White, T., 1899. 'The ceremony of Rahui'. Transactions \& Proceedings of the Royal Society of New Zealand 1868-1869 32: 352-57.

14 Henry, T., 1968. Tahiti aux temps anciens, Paris: Publication de la société des océanistes.

15 Davies, J., 1851. 
about plantations. The dimensions of the carving varies according to the rank of their owner, but anyone could carve them and practice a ritual meant to activate them, grouping them attached to stakes so as to cover all directions of the property that benefited from their protection. Stones were also put at the base of the stakes.

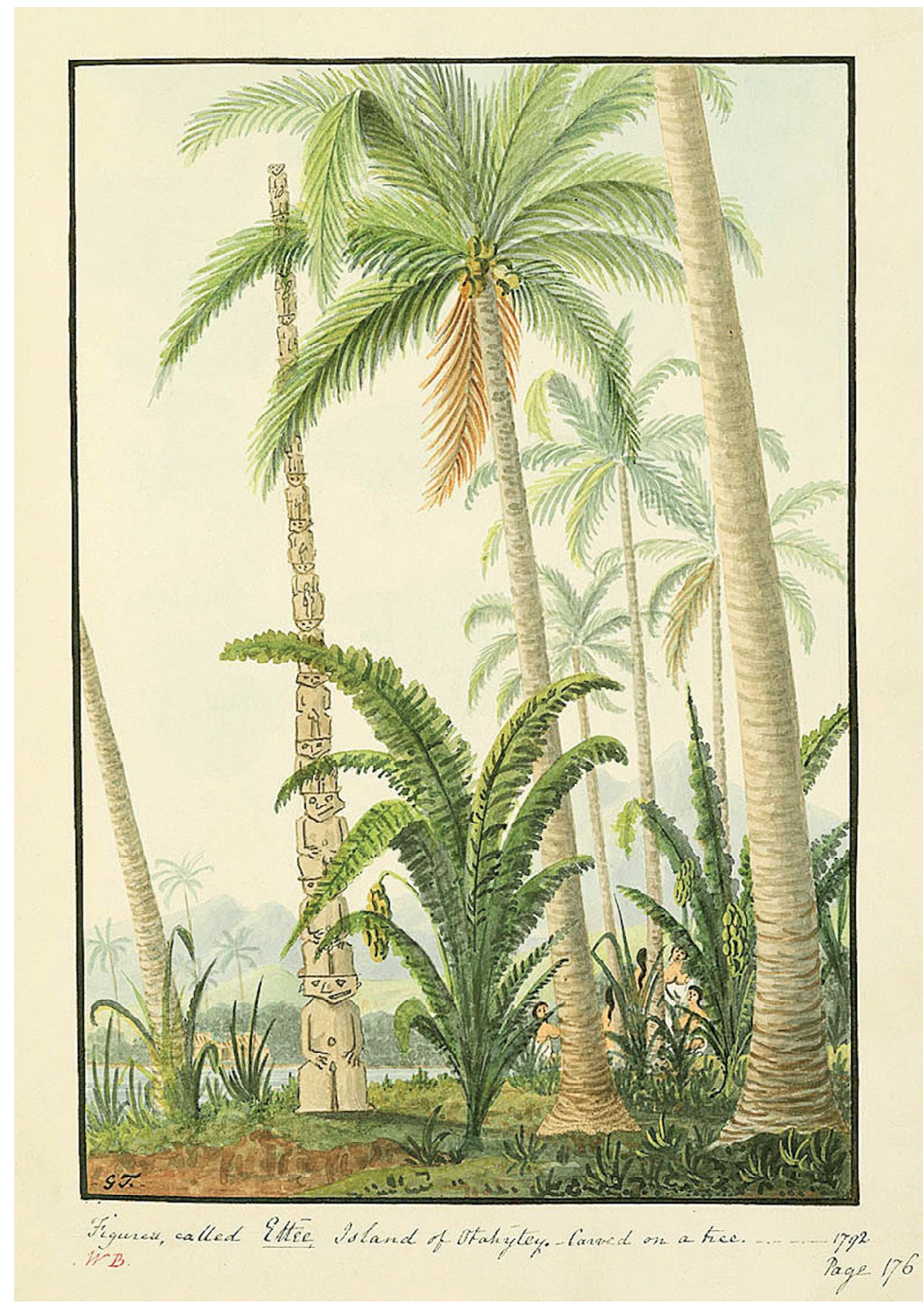

Figure 3: Carved post called ti'i potua ra'au as sign of rāhui

Source: Drawing by George Tobin, Mitchell Library 


\section{Making use of the coconut}

The coconut palm tree has many uses in making sacred objects, including the kaha, 'aha (sennit) that supports the red feathers of the god's effigy $\left(t^{\prime} o\right)$. It is thus logical that it would be called on as a symbolic mark of prohibition: niu, and its variants refers to the coconut across the Austronesian linguistic area, and the stone, which is the basis of a sacred enclosure. Images in plaited coconut palm could be used, as also in Melanesia, to indicate a prohibition. In Samoa:

the taboo was employed chiefly for the purpose of protecting plantations and fruit trees from the thieves. Each individual was supposed to have the power of tabooing his property by means of a significant symbol, without the aid of a priest, and bring punishment to those who disregarded the taboo. ${ }^{16}$

Beliefs connected with taboo signs on Samoa are given by Turner:

One of these, intended to protect a man's breadfruit trees, was a representation of a sea spike (three pointed spear), made with plaited coconut leaflets and hung from one or more trees; the idea involved was that the sea spike would run into the body of a thief, and anyone proposing to steal would be prevented by a fear, if he did so, that a sea spike would actually dart up and wound him mortally, the next time he went out to sea. ${ }^{17}$

In Anaa of the Tuamotus, the significative elements of the rāhui can be compared with those in the rest of Polynesia. At the end of the nineteenth century, the vernacular corpus of Paea-a-Avehe shows the religious importance of rites regulating fertility and the management of food resources.

\section{Protection of plantations on Anaa}

Contrary to common belief, the Tuamotuan people were as capable agriculturalists as they were sailors. The cultivating of food plants (hamo katiga) was done inside pits called maite. These pits were dug

16 Ella, cited in Williamson, R.R., 1937. Religion and Social Organization in Central Polynesia, Cambridge at the University Press. Ella later became a London Missionary Society missionary on Ouvéa, which means he was at ease with Polynesian linguistics.

17 Williamson, 1937. 
with pearl shell spades ${ }^{18}$ to sweet water level. The pits were lined with trees that produced humus through their leaves, which belonged to and was exploited by a lineage (gāti).

Plantations outside pits could be put under prohibitions, such as the species of Pandanus tectorius specifically used as a food for humans, Pandanus tectorius var. tectorius, or the one cultivated for the making of mats or objects that would be put under tapu, which is mentioned in the old songs as fara tanu, probably Pandanus tectorius var. laevis, the leaves of which are devoid of thorns. ${ }^{19}$ Another important plant used for food was the pia, Tacca leontopetaloides, which grows around the outside face of the atoll.

Part of Paea's manuscript dwells on the techniques for making use of the coconut palm on Anaa. Although this testimony belongs to the beginning of the nineteenth century, it illustrates the minute care and knowledge that was brought to bear on the use of different parts of the coconut as regulated by a system of prohibitions. There existed a system of material and symbolic codes, as among the Maori, that made sense to the whole community.

A mark called pūtiki at Anaa, as described by Paea, was intended to convey a message through a plaited coconut frond (rau gaofe) twined around the trunk. The sole fact of being plaited all round signalled the ownership of the land. The image made of the frond embodied the mauri and the power of its owner. The fruit, which was the object of the restriction, was attached to the pütiki, in this case a coconut at the ripe stage (gora). This construction was meaningful for all and indicated both ownership and prohibition.

The proto-Polynesian pūtiki stems from the root fii-tiki. The definition given by Stimson for the Tuamotu is:

To make a circle fringe, of leaves around, upon. As around a tree as a sign of restriction; or upon the head as a protection against the sun. Marked by a girdle of leaves: a sign of formal sacred restriction, prohibition. ${ }^{20}$

18 Chazine, J-M., 1985, 'Les Fosses de Culture dans les Tuamotu. Travaux en cours et Perspectives'. Journal de la Société des Océanistes 61: pp. 25-62.

19 Butaud, J.F., 2010. Guide Floristique des Atolls Soulevés de l'archipel des Tuamotu. Papeete: Direction de l'Environnement.

20 Stimson \& Marshall, 1964. 


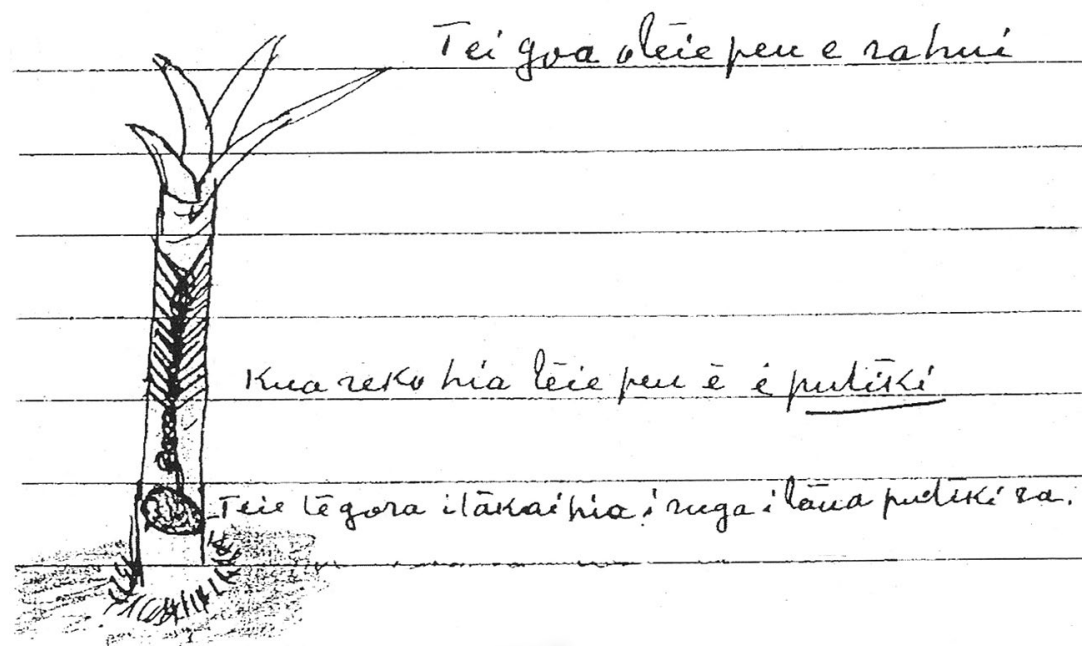

Figure 4: Pūtiki as sign of prohibition on the resource

Source: Drawing by Paea-a-Avehe, Stimson Mss, Torrente 2012

As Paea explains:

E gaohe ore, e ravehia teie peu $i$ ruga i te hakari e te tahi atu a haga rakau, e rave katoa hia hoki ei pukohu karire haiko. Te igoa o teie peu e rāhui, kua reko hia teie peu e, e pütiki. Teie te gora i takai hia i ruga $i$ taua pütiki ra. ${ }^{21}$ (The custom was to take green coconut fronds, which were placed round the coconut palm tree trunk, or round another tree, or at times pandanus leaves freshly cut. These coconut fronds were also used to fasten faggots of dry wood for the fire. This custom was also called rāhui, and more specifically pūtiki. A green coconut was hung under the pūtiki). ${ }^{22}$

In this symbol, two things take precedence. On one side, the fact that a coconut frond girds the trunk of the fruit tree signifies a temporary prohibition placed upon the food source, on the other side the hanging of a ripe coconut tells which category of food is being thus regulated.

The pürahui is mentioned on Anaa, as a generic term designating the sacred prohibition, meaning a plantation $(p \bar{u})$, put under rāhui, containing the concept of heart, of origin, of invisible centre: $p \bar{u}$,

21 Paea-a-Avehe, 'Small notebooks from Paea'. In Frank Stimson Manuscripts, Microfilms, The Peabody Essex Museum of Salem, Massachusetts.

22 Torrente, F., 2012. Buveurs de mers, Mangeurs de terres, Histoire des guerriers de Anaa, archipel des Tuamotu, Pape' ete: Te Pito o te Fenua. 
wrapped in its visible sign, rāhui. There exists on this atoll a piece of land called Pūrahui, on which is established a small marae bearing the same name. ${ }^{23}$

\section{Rāhui on parts of the lagoon}

The atoll of Anaa has a closed lagoon that was well known in the past for its abundance of pearl shells, pärau (Pintada margaritifera), or te uhi taramea (Pinna sp.), and its abundance of koeha (Tridacna maxima). The commercial diving campaigns that began in the second half of the nineteenth century diminished the resource, which obliged the imposition of a law forbidding the plundering of the lagoon of Anaa. ${ }^{24}$

The chants (fakatara) the function of which is to legitimate the land holdings of the ancient descent groups (gāti), carry the names of the lagoon areas that are rich in pearl shell (and belonging to particular chiefs), called roto pārau, and of the spots where the pearl shell are concentrated, called pū pārau. The prestigious chieftainship gāti Tagihia owned pearl shell as a guardian symbol (te uhi taramea). ${ }^{25}$

Ancient society gave the shell fauna of Anaa a primary religious and symbolic importance, the shells of the bivalves being understood as containing the atoll universe, as well as being host to all that is sacred (red feathers, or blood oozing from sacrifices). Pearl shell came into the making of all religious objects, or for the ornamentation of warriors, for example necklaces (kanaenae) and breastplates (te uhi taramea), including the famous Parata warriors of Anaa who were covered with shark skins and wore a sort of glove made from the jaw of the moray eel. ${ }^{26}$

The tapu on the shells was not only meant to protect a food resource but also, more widely, symbolic or sacred objects that were prestigious throughout Polynesia.

23 Torrente, F., 2010. Ethnohistoire de Anaa, un atoll des Tuamotu, Thèse de doctorat en Ethnologie, Anthropologie culturelle. Université de la Polynésie française.

24 Journal of 'Messenger de Tahiti'. Imprimerie du Gouvernement, Papeete, Aout 1878.

25 Torrente, 2012.

26 Torrente, 2012. 
Certain parts of the reef were marked out by pieces of white cloth (tapa) on sticks so as to indicate a restriction on the fishing of maoa shells (Turbo setosus) or pāhua, kohea (Tridacna maxima), or wider fishing inside the area. On Anaa, numerous heaps are still known as being used to demarcate the tauga paru, areas of fish concentration each of which bore a specific name.

\section{Rāhui transgression}

Intentional or not, the breaking of a tapu or a rāhui is called hara. It is meant to bring about the gods' displeasure, or to unleash the unearthly forces on the transgressor. If the fault was known, the risk was then carried by the group as a whole and seen as a disorder threatening the social cohesion - a calamity of some sort, natural or not, being thrust upon the group. This was the reason for the person at fault to be banned from his group and land of birth.

The mechanisms of the supernatural sanction are that the destructive power of the rāhui penetrate (uru) the transgressor, deteriorates his mauri and brings death if nothing is done or a knowledgeable person, a tahuga or tāura, does not practice the appropriate ritual so as to reverse the destructive process. The rites were meant to restore the mauri, and get out of the body the destructive principle linked to the rāhui. Purification rituals, making use of water or of the smoke of a tapu fire, were practised on the marae also in the case of transgression (hara) affecting the community. Some authors claim, maybe mistakenly, that this ritual could involve human sacrifice, which is a theory proposed by the proselytising agenda of missionaries and Christian zealots. ${ }^{27}$

Possession of the victims by one or more destructive forces would bring about symptoms marked by shivering and uncontrolled movements called ira, and mostly acute pain and the swelling of the belly. As noted by Reverend Orsmond:

The spirit of the coral, puga, farero, kana, lacerated the guts, the power of the stone, fatu, creating an intolerable weight (on the belly), the power of the wood, rakau, pierced the guts, bringing a strong

27 Henry, T., 1928. Ancient Tahiti. Bulletin no. 48. Honolulu: Bernice P. Bishop Museum; Pomare, T., 1971. Mémoires de Marau Taaroa, dernière reine de Tahiti, traduits par sa fille, la princesse Takau Pomare. Publication de la Société des Océanistes no. 27. Paris: Musée de l’Homme. 
fever, palpitation and foam to the mouth. When the witnesses, choken by fright, asked the forces who they might be, they would answer and give their names, saying this word first: 'O vau ...' (it is I). ${ }^{28}$

Paea explains that on Anaa the transgression of the tapu or rāhui in this instance, it would be a marae located at Napahere - caused sickness, starting with an uncontrollable shaking and a swelling of the body as with a woman with child. ${ }^{29}$ Going to a tahuga or tāura, was the only way to dominate the surnatural sickness called pona. ${ }^{30}$

Paea explains that only the purification rite performed by a tahuga could cure the sickness in these words: 'Kaore hoki e mehaki e ora ai tei te haga tahuga hoki te mehaki e ora ai te tagata i tupu hiai teie nei maki.' This swelling process is known all over Polynesia and Melanesia. ${ }^{31}$

The tahuga made a miniature canoe with a sail and a paddle ( $E$ haga rateu ki te vaka korereka te vega te hoe) that he moved around the victim's belly while speaking to the force inside: 'Hauhari mai! Hauhari mai tateu $i$ ruga $i$ to tateu vaka mai ake hau tere ka vaiho atu tena tagata! Kaveke tateu! (Come, come on our canoe and leave this man, let us go. Let us go!).'

Then he carried the canoe ceremonially unto the reef and let it run in the sea, while saying: 'Hau tere ra kauraka e noho mai kaveke tateu (Now go! Let us not stop here, let us go!).'

It is only when the canoe went away that the sickness could take away the destructive forces of the pona: 'Kia tere ra taua vaka korereka nei, ei reira taua maki nei e ora ai. Ko te huru teie i te maki reko hia ra e pona.' ${ }^{32}$

Elsewhere, pollution caused by the breaking of a tapu, or the transgression of a rāhui, could be attenuated by expiatory or purification rites that were meant to remove the contamination process.

\footnotetext{
28 Rev. Orsmond, in Henry, 1928.

29 'E tupu hiai e taua maki kiro nei e te rikarika e goru te kopu mai te hapu te huru.' This outworldly sickness was called pona: 'E reko teie no te maki rekohia ra e, e pona no Ganaia.' 30 Paea-a-Avehe, Emory Manuscripts, folio ZG 13/ 292, Bernice Pauahi Bishop Museum Archives, Honolulu, Hawai'i, translation in Torrente, 2012.

31 Guiart, J., 2013a. Malekula, l'explosion culturelle. Nouméa \& Pape'ete: Le Rocher-à-la-Voile; Guiart, J., 2013b. Cultures on the Edge, Caught Between the White Man's Concept, Polynesia Opposed to Melanesia, from Efate to Epi, Central Vanuatu. Pape'ete: Te Pito o te Fenua.

32 Paea-a-Avehe, Emory Manuscripts, in Torrente, 2012.
} 
For that purpose, two mediums were used: the tapu fire (ahi taitai), which chased or consumed the pollution by the influence of the heat or the smoke; otherwise salt or fresh water washed the impurity.

\section{Modes of lifting a rāhui or a temporary restriction}

Lifting a rāhui was part of a complex ceremonial process at the end of which food, after having been offered to the gods, would pass from the state of tapu to that of noa (free from any restriction). This process was called fakanoa, which meant not only the freedom from tapu, but also 'to bring within one's power' ${ }^{33}$ The accumulated food would then be distributed on the occasion of a feast. The rāhui had been lifted by he who had instituted it, and the signs of the restriction were taken out with some solemnity. The action of lifting tapu or rāhui was called hakamāma on Anaa and tāma on Vahitahi; the state of freedom from tapu was known as $m \bar{a}$ or māma.

The offering of the first fruits from the crop or from fishing or hunting was the ritual by which the rāhui would be lifted on the food concerned. The first fruits were cooked on a tapu fire and given as an offering to the gods.

This rite demonstrates a propitiatory dimension through which the prohibition (the sacred content linked to the tapu) was transferred to the gods who absorbed it. As Babadzan explains, this is an inversion rite through which the ritual pollution of the offering to the gods reverses the roles, putting the gods in an inferior position to humans. Offerings and incantations thus carried a consequence that made food noa for the humans to eat ${ }^{34}$ at a feast attended by the whole community.

Among the Maori, lifting the tapu when the building of a communal house was finished was obtained through the first-born girl of the highest rank eating a roasted kumara inside the building. First-born girls of high rank were classified as ariki and, as all Maori ariki, could be tahunga if they had gone through the specific training.

33 Smith, J., 1974. Tapu Removal in Maori Religion. Memoir no. 40. Wellington: The Polynesian Society.

34 Babadzan, A., 1993. Les dépouilles des dieux. Paris: Editions de la Maison des Sciences de L'Homme. 


\section{Lifting the restriction: The tiorega ritual}

The tiorega ritual ${ }^{35}$ was practised on Anaa so as to lift the tapu on food resources or on the occasion of the first captures of fish that had been placed under rāhui. Offerings were given first to the high-ranking people, ariki or tahuga, who acted as go-betweens so as to deliver them to the gods. The common people (tangata rikiriki) could eat the produce after its redistribution to all. My informant, the 75-year-old Te Neehiva-a-Horoi, still knew about this ritual, practised on a specific marae called marae tiore.

Paea talks about a special walled enclosure he calls marae tiore haga katiga; marae for the offering of first fruits, of which he has left a drawing (see Figure 5). He adds that when a coconut tree gave its first ripe nuts (teke) they were to be carried to this marae and could not be eaten before the rite of the lifting of the prohibition had taken place, otherwise the nuts would be found bad (kiro) or would fall down before being ripe, or would be found dry. The ariki, the tahuga and the principal warrior (kaito) were to receive these first fruits before they could be eaten by the common people. The same ritual was practised for the first catches of fish during their period of abundance.

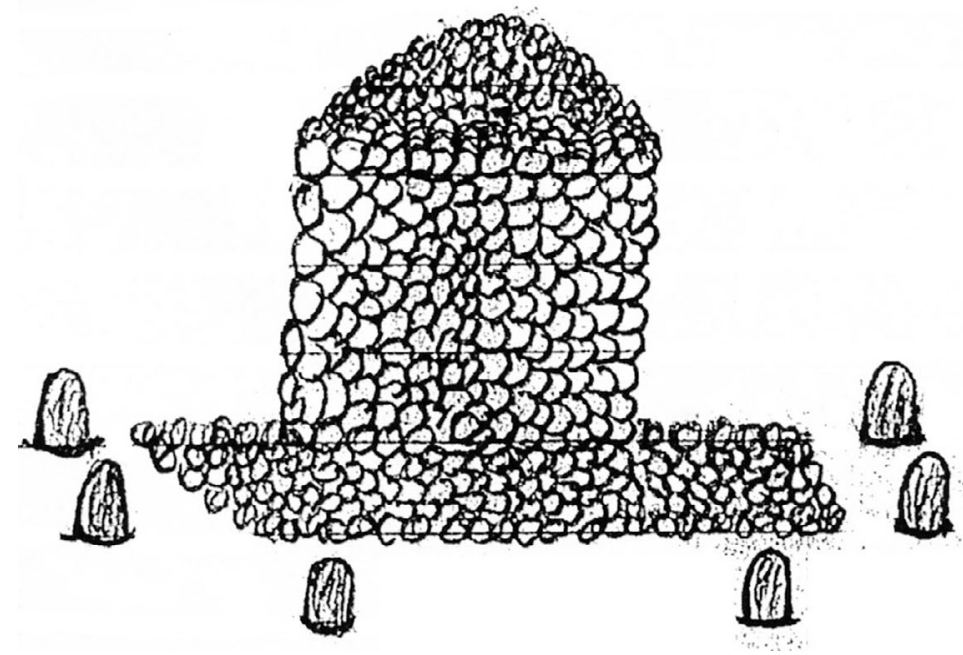

Figure 5: Temple called Marae tiore haga katiga

Source: Drawing by Paea-a-Avehe, Stimson Mss, Torrente 2012

35 The meaning of tiorega is 'eating of the first fruits' (Stimson \& Marshall, 1964); elsewhere: pāore $=$ tiore . 


\section{The gāvari ritual on Anaa}

At the occasion of the end of community work, such as the building of a high seas canoe, the end of the rāhui was announced and a ritual called gāvarihaga vaka was introduced, which allowed the lifting of the prohibitions and the opening of the canoe for its normal use. ${ }^{36}$ The same happened at the end of the building of a marae or other important community buildings.

These rites were practised on Anaa in another type of walled enclosure called marae vaiga katiga no te haga varua o te po, literally 'shrine for food offerings to the forces of the invisible world'. This was a small marae demarcated by a wall of ordinary stones, a wooden post (named $k e h \overline{)}$ ) planted exactly in the centre. The kehō had a horizontal platform fixed at its summit on which the food offerings meant for the gods (atua) or the ancestors (tuputupūa) were deposited. This marae was smaller than the ones serving as more central religious sites. On Fagatau Island, the kehō was a standing stone that was at times associated with a transverse stone piece on which to place offerings to the gods. ${ }^{37}$

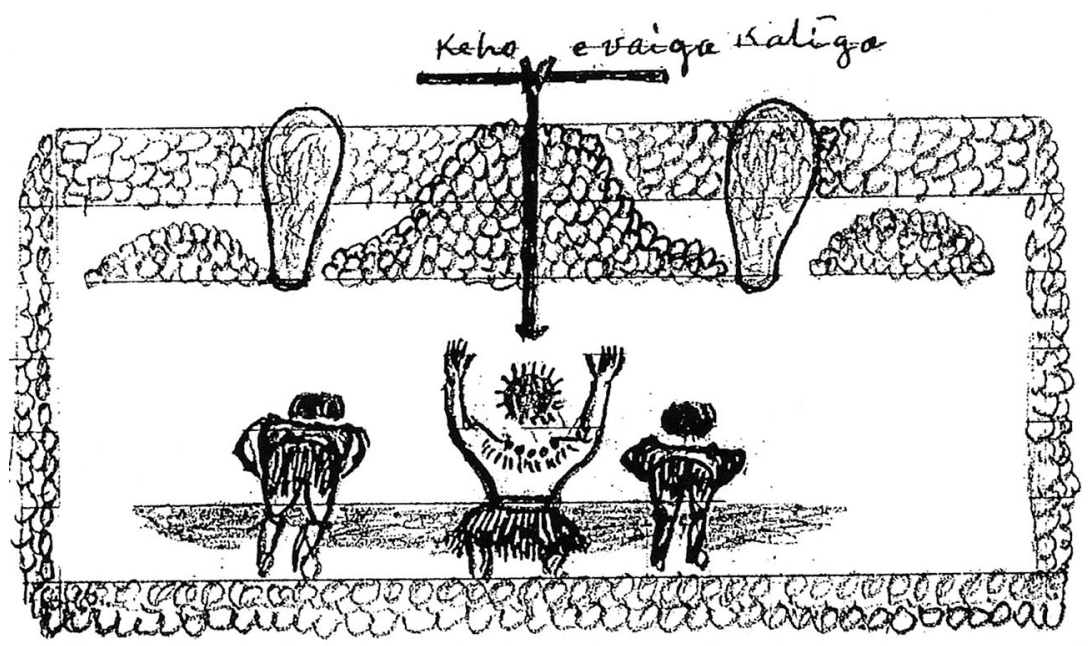

Figure 6: Temple called Marae vaiga katiga no te haga varua o te po

Source: Drawing by Paea-a-Avehe, Stimson Mss, Torrente 2012

36 Stimson \& Marshall, 1964.

37 Stimson \& Marshall, 1964. 
Feasts were celebrated seasonally, during periods of abundance or when the first seagoing turtles (Chelonia mydas) came in. The first turtle to be captured was the object of complex rites. ${ }^{38}$

\section{Conclusion}

Thus can we say that in Polynesia, each living species (of vegetable or animal kingdom) or any inert element existed within a continuum that excluded any philosophical opposition between nature and culture. The genealogical model set out the exact place of each living species, including man.

A vertical logic drew the link between the sky as being the abode of the gods, the chiefs who controlled the human order of things, and the ancestors and the world of origins, which was deep in the earth.

Each species of creation owned a visible shape, issued from the depths (tupu) and a specific appearance (huru) visible to humans, as a kind of container, an envelope, a shell. This contained an invisible interiority made of many vital elements. First, the vārua, sort of an ever-unseen double living inside this body that could survive the death of its envelope. This was the living factor behind the animation of each physical body, which explains the personification of elements seen in the natural environment, such as coral.

On the other hand, each body benefited from a life-giving energy (mauri), which allowed the manifestation of life and the reproduction of species. A vital principle runs through all things, as the sap inside a tree (iho or uho) given to man at birth by the umbilical cord, also called uho, or by the roots of plants. In man, it could be carried over generations, being present in the ancestor's relics, bones and objects, and inside a chief's lineage (iho ariki or uho ariki).

But, nobody could exist without the life-giving light, shown in the person of Atea or Tane-te-vai-te-ora. That is why the pieces of the cosmos, clouds and stars, and the living objects, animals and vegetal species, are seen as the children of Atea or Tane, according

38 Emory, K.P., 1947. Tuamotuan Religious Structures and Ceremonies. Bulletin no. 191. Honululu: Bernice P. Bishop Museum. 
to a genealogical model that links the ancestry (tuputupūa) of gods, men and animal and vegetable species, plus any understandable phenomenon that is given a mental existence.

It is not feasible here to give the details of the construction of the Polynesian cosmic order, which made of two opposing worlds: the world of light called, according to location, Ao nei or Ao marama, the world of what can be seen, of life; and the world of the Po, the one of the invisible, of the gods, of obscurity and of the original depths where the dead return to. ${ }^{39}$ There is no way of studying any living species without taking into account the parallel visible and invisible worlds.

Christianisation has erased the old frontiers between tapu and noa areas. The logic of the rāhui has changed. Fossil forms of the old religion have been retained, nevertheless, in particular in the manipulation under tapu of relics (nails, hair, liquids), clothes or objects in contact with the human body, including footprints.

The signification of the word rāhui has also changed. It is linked today to the different concepts dealing with the protection of the environment, which was not the aim in ancient Polynesia.

Translated by Jean Guiart, July 2013.

39 Stimson, J.F., 1937. Tuamotuan Legends (Island of Anaa) Part I. The Demi Gods. Honululu: Bernice Pauahi Bishop Museum Bulletin; Salmond, A., 1978. 'Te Ao Tawhito. A semantic approach to the traditional Maori cosmos'. Journal of the Polynesian Society 87(1): 5-28. 
This text is taken from The Rahui: Legal pluralism in Polynesian traditional management of resources and territories, edited by Tamatoa Bambridge, published 2016 by ANU Press, The Australian National University, Canberra, Australia. 